\title{
The Effect of Board Composition on Corporate Financial Performance: Evidence from Listed Firms in Ghana
}

\author{
Albert Puni ${ }^{1}$, Bright Addiyiah Osei ${ }^{1} \&$ Samuel Bachison Ofei ${ }^{1}$ \\ ${ }^{1}$ Department of Administration, University of Professional Studies, Ghana. \\ Correspondence: Albert Puni, Department of Administration, University of Professional Studies, Accra. P.O. Box \\ LG 149, Legon, Ghana. Tel: 233-244-215-904. E-mail: albertpuni2000@yahoo.co.uk
}

Received: April 28, 2014

Accepted: June 14, 2014

Online Published: July 25, 2014

doi:10.5539/ijbm.v9n8p170

URL: http://dx.doi.org/10.5539/ijbm.v9n8p170

\begin{abstract}
This study adds to the literature on corporate governance and corporate financial performance by assessing the effect of board composition on the financial performance of listed firms in Ghana. Using a static panel regression model, the results show that contrary to the agency theory, inside directors tend to have a positive and significant effect on corporate financial performance whilst outside directors have a negative but statistically insignificant effect on corporate financial performance of the listed firms in Ghana. In addition, it was found that the existence of nomination committees tend to have a negative effect on corporate financial performance of listed firms in Ghana. The study recommends that listed firms in Ghana should look at how to continuously empower inside directors to be able to perform their work well instead of bringing in more outside directors to check them. Moreover, the nomination process of board members must be made transparent to achieve the objective of recruiting competent and ethical minded executives to the board. Guidelines for executive recruitment to the board must be established and if possible the nomination committee must employ the services of executive-hunting agency which would assist the committee in the recruitment process.
\end{abstract}

Keywords: agency theory, stewardship theory, board composition, corporate governance, corporate financial performance

\section{Introduction}

Corporate governance (CG) is bedeviled with an old-age challenge of what is so-called the "agency problem" from a theoretical perspective due to the separation between ownership and management (Beale \& Means, 1932). The distinguishing feature of the separation of ownership and control of the modern corporation is that the owners of the corporation (shareholders) being principals with accumulated capital have hired rational executives (agents) with expertise and ideas to manage the company on their behalf. As both parties have separate utility functions and the agent is more informed about what is going on in the firm than the principal the agency problem occurs. The penalties of the agent's secret shirking in the relationship known as the Agency Cost, can manifest itself in various form including self-serving behaviour which is focused on status or empire-building objectives, excessive perquisite consumption, non-optimal investment decision-making or acts of accounting mismanagement and corporate fraud (Biswas, 2010).

Conceptually, the agency problem is adequately addressed by ensuring that board composition provide for the separation of the management and control decision functions between inside and majority outside directors so that none of them in the decision making process can have unnecessary advantage that will jeopardize the value maximization objectives of owners (shareholders).It is believed that board composition characterized with majority outside directors provide maximum control and prevent conflict of interest challenges than a board composed of majority inside directors (McColgan, 2001). The separation of functions ensures maximum checks and balances, and prevent inside directors from dominating board decision-making process thereby minimizing the agency cost associated with inside directors' dominance.

Several corporate governance literature have examined the monitoring role of corporate boards however previous researches investigating the effect of majority outside director board composition structure on Corporate Financial Performance (CFP) have revealed contradictory results. Many of the studies exposed that majority outside directors brings independence resulting from superior objectivity in monitoring executive behaviour (Frankel et al., 2011; Armstrong et al. 2010; Klein, 2002; Krishnan, 2005; Peasnell et al., 2005). 
However, there are others who are of the view that apart from the skill and expertise inside directors bring to strategy formulation, they equally ensure that the internal control mechanisms are effective to assure owners that the company objectives will be achieved (Chen et al., 2012; Armstrong et al. 2010). Though the evidence are conflicting, in several jurisdictions, regulators have promulgated codes suggesting the implementation of board composition of majority outside directors among shareholder companies such as the Combined Code of United Kingdom (UK) (2003), the King's Code of Corporate Governance of South Africa (2009), and the Corporate Governance Guidelines on Best Practice Code (CGGBPC) (2004) of Ghana with the singular objective of minimizing the agency cost of possible opportunistic behaviour by inside directors thereby enhancing CFP. For example the CGGBPC (2004) suggest that;

The board of listed companies should include a balance of executive and non-executive directors with the complement of independent non-executive directors being at least one third of the total membership of the board and in any event not less than two (CGGBPC, $p .17)$.

Since the introduction of the CGGBPC (2004) there are growing numbers of listed companies that have voluntarily complied with the recommendations with the expectation that the suggested board composition of majority outside directors' principle will reduce the agency problem and improve CFP. However, in Ghana the authors are not aware of any research that has investigated the effect of complying with the majority outside directors' board composition principle and its effect on CFP. Since the adherence of this principle entails incurring substantial cost by listed companies, an investigation ascertaining the effect of board composition on CFP is necessary because shareholders, the investing public, regulators and academics will be informed about which of the two set of directors (inside or outside directors) constituting board composition has positive and significant effect on CFP among listed companies in Ghana. This study is important as it seeks to estimate how effective the introduction of some of the corporate governance structures in the CGGBPC (2004) has contributed to CFP. Thus, this research seeks to investigate the effect of board composition (inside or outside directors) on CFP. Based on the above objective the following hypotheses were tested to ascertain the effect of board composition and CFP.

\section{$\mathrm{H}_{0}$ : Inside directors have a negative effect on CFP.}

$\mathrm{H}_{1}$ : Independent outside directors has apositive effect on CFP.

It must be added that not much has been done in this area since the promulgation of this code in 2004. The study is structured as follows: Section one (1) deals with the introduction whilst section two (2) provides a review of both theoretical and empirical literature relating corporate financial performance and corporate governance, most importantly, board structure and composition. Section three (3) addresses the method used in achieving the objectives and hypothesis. Section four (4) presents the results and discussions while section five (5) provides conclusions and recommendations from the results.

\section{Literature Review}

\subsection{Agency Theory}

The issue of corporate governance and corporate financial performance has traditionally revolved around the agency theory. The agency theory is a concept which expresses a contractual relationship between two parties often referred to as the principal and agent (Shapiro, 2005). The principal engages the agent based on strict instructions to perform specified services on his or her behalf. The principal's delegated powers are directed towards the utilization of key resources by the agent, and it is expected that the agent uses his or her specialized proficiency to multiply the wealth of the principal (Clake, 2004). Due to the information asymmetrical problems in this relationship, the principal institute control mechanisms of which board composition is part to protect the principal from the possible selfish behaviour by the agent. The provision of incentives to the agent is paramount in this relationship based on performance and this is aside the monthly remuneration the agent receives. Additionally, the agent is expected to be accountable at all times to the principal and the agent will only maintain his or her position based on the achievement of the performance target set by the principal (Stanton, 1997; Romzek \& Dubnick, 2002).

From the agency perspective, board composition has been identified as one of the mechanisms when implemented effectively will reduce the agency cost and lead to the enhancement of corporate performance. The theory suggests board composition, characterized by the separation of functions between inside and outside directors, ensures maximum control which promotes fairness, objectivity, transparency, and accountability at the board level. It advocates for board composition of largely independent outside directors because of the suspicion of opportunism by inside directors in the presence of information asymmetry (Fama \& Jensen, 1983). 
The agency theory emphasized majority independent outside directors because such persons are presumed impartial because they are not employees of the company and as such do not partake in the executive management's compensation packages aside their board fees and allowances. The presence of majority independent outside directors is viewed by the agency theory as a surest structural board mechanism in preventing opportunistic agents (executives) from the consumption of private perquisite (Zubaidah, 2009). Theoretically, a board is described as independent if it is made up of more outside directors that share no material connection such as family ties, financial relationship, employment, professional services, and interlocked directorship amongst others with the management (Ayuso \& Argandoña, 2007; Shivdasani \& Zenner, 2002).

The theory further posits that board composition comprising of independent majority outside directors is better placed to exercise decision control because they may have their reputation to protect especially under circumstances where they do not have equity stake in the company (Christensen et. al., 2010; McClogan, 2001). The presence of board composition with majority independent outside directors has been referred to by the agency theory as control mechanism for disciplining non-performing management and supporting takeovers once it is in the interest of shareholders (Weisbach, 1988).

\subsection{Stewardship Theory}

There are other theories that have opposed the agency view. Principal among them is the stewardship theory which originated from the fields of psychology and sociology (Abdullah et al, 2009). Whereas the agency perspective assumes a rational being whose behaviors are underlined by economic consideration and must be monitored and incentivized to produce the necessary cooperation between the agent and the principal, the stewardship theory predicts an attitude of self-inspired desire or an inner drive directed towards executing difficult task and taking responsibility to earn the needed respect from colleagues and superiors that results in an in-built satisfaction and fulfillment by the individual from such behavior (McClelland 1961; Herzberg et al. 1959).

The stewardship theory views man as trustworthy-being whose personal utility is maximized when the principal succeeds. The issue of trust between the steward and principal or followers has been extensively explored by many researchers (Bachmann \& Zaheer, 2006; Hardin, 2002; Kramer \& Cook, 2004; Kramer, 2006). In a stewardship relationship, the principal (trustor) is prepared to be defenseless to the dealings of the steward (trustee) based on the assumption that the steward (trustee) will do everything possible to see the principal's wealth increased even if there are conditions that encourages opportunism. Consistently, the stewardship theory supports board composition of majority inside directors since the theory believes that inside directors are trustworthy, possess the collectivism mentality and in the presence of information asymmetry, will seek the value maximization of the principal because by doing so, the stewardship agents wealth is multiplied. The stewardship board combines both the decision management and the decision control functions because of the trust element within the principal-agent relationship.

\subsection{Board Composition and Financial Performance}

Empirically, evidence of inside directors on CFP is sharply divided among the agency and stewardship theories, with others disagreeing with both debates. Stewardship-anchored researches which favor inside directors have established that when boards are made up of majority inside directors they are more likely to resist hostile take-over (shark repellents) which protects the company from corporate raiders (Frankforter et al., 2002; Carter et al., 2003). Similarly, Donaldson and Davis (1991) found that boards with greater proportions of inside directors were associated with higher CFP especially when the board chair was also the CEO (CEO duality). Similarly, Arthurs et al., (2008) revealed that inside directors had positive influence on the pricing of Initial Placement Order (IPO). The whole stewardship evidence suggests that whenever inside directors in the delivery of their work are unimpeded by outside directors they would be inspired to do more than expected to achieve higher CFP (Davis et al., 1997). Surprisingly, manyof the studies connecting inside directors to CFP sought to suggest an environment characterized by the presence of high shareholder concentration (Schipani \& Liu 2001; Tam 2002; Tan \& Wang 2004; Fe inerman, 2007; Wang 2007).

Evidence relating outside directors to CFP are equally varied and inconclusive. Firstly, (Haniffa et al 2006; Hooghiemstra \& Van Manen, 2004; Bhagat \& Black, 2000; MacAvoy et al. 1983; Hermalin \& Weisbach, 1991; and Klein, 1998) all revealed negative relationship between outside directors and accounting performance indicators whilst (Zubaidah, 2009; Shleifer \& Vishny, 1997; Dehaene et al., 2001) found positive effect between majority outside director and CFP. In the case of the negative effect, Hooghiemstra \& Van Manen, (2004) noted that stakeholders are generally not satisfied with the supervisory role of outside directors. Correspondingly, 
Haniffa et al. (2006) concluded that high proportions of outside directors result in excessive monitoring which stifle innovation and creativity on the part of inside directors, and lack of business knowledge which make decision making and discussions at board level more cumbersome (Baysinger \& Butler, 1985; Patton \& Baker, 1987; Demb \& Neubauer, 1992; Goodstein, Gautum \& Boeker, 1994). Based on the theoretical and empirical review, this study looks at how board composition comprising inside and outside directors, together with other corporate governance structures influence CFP.

\section{Methodology}

\subsection{Research Design}

The positivist research methodological approach was adopted to examine key variables of board composition that contributed to CFP. The approach then necessitated the testing of board composition initiated by the regulator to reduce the agency problem and contributed to CFP. The quantitative research method was employed in this study.

\subsection{Data Source and Sampling}

The study sourced data from the Ghana Stock Exchange (GSE) Fact Book (2010). The Fact Book (2010) is a compilation of five year annual reports of listed companies by the GSE from 2006-2010. The data component of the annual reports was extracted for analysis. The data was extracted for firms that has been listed on the Ghana Stock Exchange as at 2006 and has been consistently listed over the study period.In all, 29 out of 36 firms from various sectors of the economy listed on the stock exchange consistently for the period were used in this study.

\subsection{Model Specification}

The study attempts to estimate the effect of board composition on the performance of corporate entities in Ghana. Following Sanda et al (2005) and Larckey et al (2007), the study considers board composition together with other corporate governance indicators and their effect on corporate financial performance in Ghana.

$$
Y_{i t}=\alpha+\beta_{i} I D_{i t}+\partial_{i} O D_{i t}+\sum \theta_{i} X_{i t}+U_{i t}
$$

The $Y_{i t}$ in the model shows the dependent variable in the study which is a measure of CFP. The key board composition variables used in this study are inside directors (ID) and outside directors (OD) which constitute the focus of the study. $X_{i t}$ is a set of explanatory variables used in the model to control for the effect of other corporate governance policies on CFP. The $\alpha$ in the model is a constant while $\mu_{i t}=\mu_{i}+v_{i t}$ where $\mu_{i}$ is the company specific effects which denotes the unobservable individual effects and $v_{i t}$ is a random term. $\beta_{i}$ and $\partial_{i}$ denote the coefficients for the key explanatory variables. The subscripts $i$ and $t$ denoting the cross-sectional and time-series dimensions respectively.

CFP is measured by two accounting based measures (ROA and ROE). ROA is measured as Net profit as a percentage of the total assets. ROE is measured as Net profit as a percentage of the equity value.ID is measured by the proportion of inside directors sitting on the board of the firm while OD is proportion of outside directors sitting on the board. Other variables used to control for the effect of the board composition on CFP includes shareholder concentration, CEO-chairman position and the existence of board committees (nomination and audit). Shareholder concentration is measured as the ratio of the proportion of shares owned by the largest shareholders to the number of largest shareholders. CEO-Chairman is measured as a binary variable which takes a value of 1 if the $\mathrm{CEO}$ is the same as the board chairman of the firm and 0 otherwise. In the same way, the existence of audit and nomination committees in a firm will take a value of 1 and 0 otherwise.

\subsubsection{Estimation Technique}

A static panel regression model was estimated to analyze the effect of board composition on CFP. The advantage of using panel data is that it helps in controlling for individual heterogeneity. Since board composition was being considered over five year period (time-series), the tendency of not controlling for the heterogeneity will run the risk of obtaining biased results (Moulton, 1987; Baltagi, 2005). Similarly, the panel data provided more informative data, more unpredictability, less collinearity among variables, more degree of choice and more efficiency (Baltagi, 2005).

Panel data models are usually estimated using either fixed-effects or random effects models. In the fixed effects model, the individual-specific effect is a random variable that is allowed to be correlated with the explanatory variables. The rationale behind random effects model is that, unlike the fixed effects model, the individual specific effect is a random variable that is uncorrelated with the independent variables included in the model. The fixed effects model is an appropriate specification if we are focusing on a specific set of $\mathrm{N}$ firms and our inference is restricted to the behavior of these sets of firms (Baltagi, 2005). The quandary of choosing the most 
appropriate model (fixed or random effect) was overcome by performing the Hausman test to find which of these models is the most appropriate. Moreover, a correlation of the variables is undertaken to ascertain their strength of association so as to avoid the problem of multicollinearity.

\section{Results and Discussions}

\subsection{Results}

The results are presented in this section. The summary statistics of the variables are provided in Table 1 . The table shows that the maximum inside directors (ID) of a listed firm is 3 whilst some of the firms had a maximum of 14 outside directors (OD). The audit committee (AC), nomination committees (NC) and CEO-chairman separation are all represented by dummies of 0 for non-existence of any of them and 1 otherwise. Shareholder concentration has a mean of 18.14 with a maximum of 23.4 .

Table 1. Summary of variables

\begin{tabular}{llllll}
\hline Variable & Obs & Mean & Std. Dev. & Min & Max \\
\hline id & 145 & 2.062069 & 1.49174 & 1 & 3 \\
od & 145 & 6.462069 & 1.914929 & 3 & 14 \\
ac & 145 & 0.931035 & 0.254274 & 0 & 1 \\
nc & 145 & 0.151724 & 0.359997 & 0 & 1 \\
ceochair & 145 & 0.131035 & 0.338608 & 0 & 1 \\
sc & 145 & 18.14382 & 3.868434 & 7.5725 & 23.39 \\
roa & 145 & 0.295207 & 0.215263 & -0.35837 & 0.784 \\
roe & 145 & 0.263756 & 0.365513 & -0.71245 & 0.894563
\end{tabular}

Source: Authors' calculation from GSE Factbook (2010).

The performance indicators, ROA and ROE, also had a mean of 0.29 and 0.26 respectively. The minimum ROA is -0.36 with a maximum of 0.78 .

Table 2. Correlation of variables

\begin{tabular}{|c|c|c|c|c|c|c|c|c|}
\hline Variable & id & od & $\mathrm{ac}$ & $\mathrm{nc}$ & ceochair & $\mathrm{sc}$ & roa & roe \\
\hline id & 1 & & & & & & & \\
\hline od & -0.1608 & 1 & & & & & & \\
\hline $\mathrm{ac}$ & -0.0436 & 0.2228 & 1 & & & & & \\
\hline $\mathrm{nc}$ & 0.4091 & 0.2502 & 0.1151 & 1 & & & & \\
\hline ceochair & -0.2499 & -0.1047 & 0.025 & -0.1642 & 1 & & & \\
\hline $\mathrm{sc}$ & 0.112 & 0.171 & -0.0353 & -0.0199 & 0.2954 & 1 & & \\
\hline roa & -0.0105 & 0.094 & 0.0183 & -0.1216 & 0.0451 & 0.1568 & 1 & \\
\hline roe & 0.1535 & -0.1409 & -0.0727 & -0.1497 & 0.1053 & 0.1534 & 0.4518 & 1 \\
\hline
\end{tabular}

The correlation matrix shows that there exists a negative relationship between inside directors and return on assets (ROA) but a positive relationship between the inside directors and the return on equity (ROE). Outside directors also had a contradictory relationship with the two performance indicators used in this study. Whilst it exhibits a positive relationship with the ROA, it has a negative relationship with the ROE. The results also show that having the same CEO as chairman of the board tend to have a positive relationship with corporate financial performance. Since all the correlation coefficients are very small, it shows that there cannot be a problem of multicollinearity. Thus, a panel regression is estimated. The Hausman test shows that the random effect model provides consistent estimates over the fixed effect model since the overall statistic chi $2=2.50$ is statistically insignificant (Prob $>\mathrm{Chi} 2=0.8683$ ) and, therefore, was selected over the fixed effect model. 
Table 3. Board composition and financial performance

\begin{tabular}{lll}
\hline & ROA & ROE \\
\hline id & 0.0108 & $0.0605^{* *}$ \\
& $(0.0148)$ & $(0.0244)$ \\
od & -0.0144 & -0.0092 \\
& $(0.0109)$ & $(0.0180)$ \\
ac & 0.0152 & -0.0361 \\
& $(0.0725)$ & $(0.1198)$ \\
nc & $-0.1088^{*}$ & $-0.2211^{* *}$ \\
& $(0.0588)$ & $(0.0971)$ \\
sc & 0.0067 & 0.0094 \\
& $(0.0052)$ & $(0.0086)$ \\
ceochair & 0.0072 & 0.1051 \\
& $(0.0597)$ & $(0.0985)$ \\
cons & 0.0599 & 0.0802 \\
& $(0.1185)$ & $(0.1956)$ \\
\hline$N$ & 145 & 145 \\
Wald Chi-2 & 17.7355 & 16.1385 \\
Prob & 0.0102 & 0.0130 \\
R2 & 0.1415 & 0.4512 \\
\hline
\end{tabular}

Note. Standard errors in parentheses: ${ }^{*} p<0.10,{ }^{* *} p<0.05,{ }^{* * *} p<0.01$.

\subsection{Discussions}

The results indicated by table 3 above shows that inside directors had positive effects on ROE at statistically significant level of 5\%. The results disagree with the agency theory which predicts possible conflict of interest issues and less oversight responsibilities when there are more inside than outside directors (McColgan, 2001). Thus, the null hypothesis is rejected at the $5 \%$ level of significance and the alternate hypothesis that inside directors have a positive effect on firm performance is accepted. Conversely, outside directors showed negative effect on both ROA and ROE, implying that hypothesis $\mathrm{H}_{1}$, is rejected.

The finding is a refutation of the general view that boards with majority outside independent directors is associated with vigorous monitoring and CFP. The positive regression of inside directors on CFP leans towards the stewardship theory which predicts positive effect of majority inside directors on CFP. The result associating inside directors to CFP is consistent with Shan et al. (2011) and Berkman et al. (2005) studies conducted in emerging economies of China and India, similar to Ghana's CG environment characterized by high shareholder concentration, weak regulatory CG framework, and developing capital market.

A survey of the Ghanaian CG environment revealed that the average holding of the top four owners of the ten largest listed firms was $70 \%$ in 2005 (ROSC, 2005). Additionally, many of the listed companies have government as majority shareholder. The corporate legal framework (Companies Code, 1963, Act 179) which serves as underlining legal structure for regulatory purposes is grossly inadequate since it has become obsolete and does not favor board independence. Reasons accounting for the positive regression by inside directors on CFP can be attributable to better information resource possessed by inside directors about the firm and expert power used in influencing decisions at board level (Baysinger \& Hoskisson, 1990). Consistently, the findings also suggest that in certain jurisdiction the implementation of the majority outside director principle does not generate CFP since the monitoring responsibilities expected from outside directors are ineffective probably due to independence issue.

In the case of outside directors, the negative effect on both ROA and ROE even though statistically insignificant is consistent with Hooghiemstra and van Manen, (2004) but inconsistent with the agency theory's prescription which predicted positive effect on CFP with board composition of majority outside directors. As part of their findings Hooghiemstra and van Manen, (2004) suggested that stakeholders are generally not satisfied with the supervisory role of outside directors. Similar studies showing negative effect of outside directors on the accounting variables concluded that high proportions of outside directors result in excessive monitoring which stifle innovation and creativity on the part of inside directors. Also outside directors lack of business knowledge which make decision making and discussions at board level more cumbersome, and issues of conflict of interest in situations where outside directors lack real independence came out strongly in their discussions (Haniffa, 2004; 
Baysinger \& Butler, 1985; Patton \& Baker, 1987; Demb \& Neubauer, 1992)The results also revealed that the existence of nomination committees tend to have a negative effect on CFP of firms listed on the stock exchange in Ghana. However, audit committees, shareholder concentration and the separation of CEO and chairman of the firm do not have a statistically significant effect on CFP.

\section{Conclusions and Recommendations}

\subsection{Conclusions}

The study has revealed that board composition of majority inside directors has positive effect on CFP whiles composition of majority outside directors regressed negatively on performance. The research has indicated that the general view expressed through the agency theory that majority outside directors in the presence of information asymmetry provides maximum control decision function thereby reducing the agency problem is not supported in all instances. There are some jurisdictions where generally the capital market is undergoing development and weak regulatory nature of the environment the stewardship of inside directors becomes an antidote to CFP than majority outside directors whose presence are do not affect performance.

\subsection{Recommendations}

The study therefore recommends that listed firms should pay attention to inside directors and empower them to be able to perform their duties instead of making efforts to increase the number of outside directors on the boards. Moreover, the regulatory environment should be looked at again since the companies code which is to regulate the firms was promulgated about four decades ago. In addition, it is recommended that the nomination process of board members must be made transparent to achieve the objective of recruiting competent and ethical minded executives to the board. Guidelines for executive recruitment to the board must be established and if possible the nomination committee must employ the services of executive-hunting agency which would assist the committee in the recruitment process, especially those directors recruited with the objective of adding the necessary competency to specialized committees on the board should followed strictly transparent procedures. If possible, the qualification of executives should be narrowed to specific subject disciplines consistent with the functions of the committee in question.

\section{References}

Abdullah, S. N. (2004). Board composition, CEO duality and performance among Malaysian listed companies. Corporate Governance: International Journal of Business in Society, 4(4), 47-61. http://dx.doi.org/10.1108/14720700410558871

Armstrong, C., Barth, M., Jagolinzer, A., \& Riedl, E. (2010). Market reaction to the adoption of IFRS in Europe. The Accounting Review, 85(1), 31-61.

Ayuso, S., \& Argandoña, A. (2007). Responsible corporate governance: Towards a stakeholder board of directors? IESE Business School, Working Paper No. 701. Retrieved from http://www.iese.edu/research/pdfs/DI-0701-E.pdf

Bachmann, R., \& Zaheer, A. (2006). Handbook of Trust Research (1st ed.). Edward Elgar Publishing Limited.

Bathala, C. T., \& Rao, R. P. (1995). The Determinants of Board Composition: An Agency Theory Perspective. Managerial and Decision Economics, 16, 59-69. http://dx.doi.org/10.1002/mde.4090160108

Baysinger, B. D., \& Butler, H. D. (1985). Corporate Governance and the Board of Directors: Performance Effects of Changes in Board Composition. Journal of Law, Economics and Organization, 1, 101-124.

Baysinger, B. D., \& Hoskisson, R. E. (1990). The Composition of Boards and Strategic Control: Effects on Corporate Strategy. Academy of Management Review, 15, 72-87.

Berkman, L. F., Glass, T., Brissette, I., \& Seeman, T. E. (2000). From social integration to health: Durkheim in the new millennium. Social Science \& Medicine, 51(6), 843-857. http://dx.doi.org/10.1016/S0277-9536(00)00065-4

Berle, A. A., \& Means, G. C. (1932). The modern corporation and private property. New York: Macmillan.

Brown, S., Hillegeist, S., \& Lo, K. (2004). Conference calls and information asymmetry. Journal of Accounting and Economics, 37(3), 343-366.

Carter, D. A., Simkins, B. J., \& Simpson, W. G. (2003). Corporate governance, board diversity, and firm value. Financial Review, 38, 33-53. http://dx.doi.org/10.1111/1540-6288.00034

Chaghadari, M. F. (2011). Corporate Governance and Firm Performance 2011 International Conference on 
Sociality and Economics Development. IPEDR, 10 .

Christensen, J., Kent, P., \& Stewart, J. (2010). Corporate governance and company performance in Australia. Australian Accounting Review, 20(55). http://dx.doi.org/10.1111/j.1835-2561.2010.00108.x

Clarke, T. (2004). Theories of Corporate Governance: The Philosophical Foundations of Corporate Governance. London: Routledge.

Cole, G. G., Kentridge R. W., \& Heywood, C. A. (2004). Visual salience in the change detection paradigm: the special role of object onset. J. Exp. Psychol. Hum. Percept. Perform, 30, 464-477. http://dx.doi.org/10.1037/0096-1523.30.3.464

Davis, G. F., \& Greve, H. (1997). Corporate elite networks and governance changes in the 1980s. American Journal of Sociology, 103, 1-37.

Demb, A., \& Neubauer, F. F. (1992). The Corporate Board. Oxford: Oxford University Press.

Donaldson, L., \& Davis, J. H. (1991). Stewardship Theory or Agency Theory: CEO governance and shareholder returns. Australian Journal of Management, 16, 49-65. http://dx.doi.org/10.1177/031289629101600103

Dubnick, M. J., \& Barbara, S. R. (1993). Accountability and the Centrality of Expectations in American Public Administration in research in public administration. Jai Press. http://dx.doi.org/10.1177/0020852300661004

Fama, E. F., \& Jensen, M. C. (1983). Foundations of Organizational Strategy. Journal of Law and Economics. Harvard University Press. Retrieved from http://papers.ssrn.com/sol3/paper.taf?ABSTRACT_ID=94034

Frankfurter, G. M., \& Wood, B. Jr. (2002). Dividend policy theories and their empirical tests. International Review of Financial Analysis, Elsevier, 11(2), 111-138. http://dx.doi.org/10.2753/REE1540-496X450401

Goodstein, J., Gautam, K., \& Boeker, W. (1994). The effect of Board Size and Diversity on Strategic Change. Strategic Management Journal, 15, 241-250.

Haniffa, R., \& Hudaib, M. (2006). Corporate Governance Structure and Performance of Malaysian Listed Companies. Journal of Business Finance and Accounting, 33(7-8), 1034-1062. http://dx.doi.org/10.1111/j.1468-5957.2006.00594.x

Hardin, R. (2002). Trust and Trustworthiness. New York: Russell Sage Foundation.

Hermalin, B. E., \& Michael, W. (1998). Endogenously chosen boards of directors and their monitoring of the CEO. American Economic Review, 88, 96-118.

Hermalin, B. E., \& Michael, W. (2003). Boards of Directors as an Endogenously-Determined Institution: A Survey of the Economic Literature. Economic Policy Review, 9, 7-26.

Hermalin, B. E., \& Weisbach, M. S. (1991). The Effects of Board Composition and Direct Incentives on Firm Performance. Financial Management, 101-112.

Herzberg, F., Mausner, B., \& Snyderman, B. (1959). The Motivation to Work. New York: John Wiley.

Holmstrom, B. (2005). Pay without Performance and the Managerial Power Hypothesis: A Comment. Journal of Corporation Law, 30, 703-713.

Hooghiemstra, R., \& Van Manen, J. (2004). The independence paradox: (Im)possibilities facing non-executive directors in The Netherlands. Corporate Governance, 12, 314-324. http://dx.doi.org/10.1111/j.1467-8683.2004.00372.x

Klein, A. (1998). Affiliated Directors: Puppets Of Management Of Effective Directors? Working Paper, New York University.

Kramer, R. M., \& Cook, K. S. (2004). Trust and distrust in organizations: dilemmas and approaches. New York, NY: Sage. http://dx.doi.org/http://dx.doi.org/10.1017/S0047279405219438

Macavoy, P., Cantor, S., Dana, J., \& Peck, S. (1983). All Proposal for Increase Control of the Corporation by the Board of Directors: An Economic Anlysis in Statement of the Business Roundtable on the American Law.

Masood, F. C. (2011). Corporate Governance and Firm Performance International Conference on Sociality and Economics Development. IPEDR, 10.

McColgan, P. (2001). The agency theory and corporate governance: A review of literature from UK perspective. UK, Glasgow: University of Strathclyde.

Mehran. (1995). Executive Compensation Structure, Ownership, and Firm Performance. Journal of Financial 
Economics, 38(2), 163-84.

Moldoveanu, M., \& Martin, R. (2001). Agency theory and the design of an efficient governance mechanism. Working Paper, Rotman School of management, University of Toronto, Canada.

Mullins J. (1999). Management and organizational behavior (5th ed.). Chicago: Prentice Hall,

Pamela, M. C., Sarah, E. M., \& Tracy, A. (nd). Dennis Emotion Regulation as a Scientific Construct: Methodological Challenges and Directions for Child Development Research.

Panasian, C., Prevost, A. K., \& Bhabra, H. S. (2008). Voluntary Listing Requirements and Corporate Performance: The Case of the Dey Report and Canadian Firms. Financial Review, 43(1), 129-158.

Patton, A., \& Baker, J. (1987). Why do Directors Not Rock the Boat? Harvard Business Review, 65, $10-12$.

Peng, B., \& Filatotchev. (2003). Do outside directors and new managers help to improve firm performance? An exploratory study in Russian privatization. Journal of World Business, 38, 346-360.

Prevost, A. K., Rao, R. P., \& Hossain, M. (2002). Determinants of Board Composition in New Zealand: A Simultaneous Equation Approach. Journal of Empirical Finance, 9, 373-397.

Sarkar, J., \& Sarkar, S. (2000). Large Shareholder Activism in Developing Countries: Evidence from India. International Review of Finance, 1(3).

Schipani, C., \& Liu, J. (2001). Corporate governance in China; then and now. Working paper no. 407. William Davison Institute.

Shan, Y., Goodrum, P. M., Zhai, D, Haas, C., \& Caldas, C. H. (2011). The impact of management practices on mechanical construction productivity. Construction Management and Economics, 29(3), 305-316.

Shivdasani, A., \& Zenner, M. (2002). Best practices in corporate governance: What two decades of research work. New York: Salomon Smith Barney.

Uadiale, O. M. (2010). The Impact of Board Structure on Corporate Financial Performance in Nigeria. International Journal of Business and Management, 5(10), 155-166.

Weisbach, M. (1988). Outside Directors and CEO Turnover. Journal of Financial Economics, 20, 431-60.

Williamson, O. E. (1984). Corporate Governance. Faculty Scholarship Series Paper 4392. Retrieved from http://digitalcommons.law.yale.edu/fss_papers/4392

Zubaidah, Z. A., Nurmala, M. K., \& Kamaruzaman, J. (2009). Board structure and corporate performance in Malaysia. International Journal of Economic and Finance, 1(1), 150-164.

\section{Copyrights}

Copyright for this article is retained by the author(s), with first publication rights granted to the journal.

This is an open-access article distributed under the terms and conditions of the Creative Commons Attribution license (http://creativecommons.org/licenses/by/3.0/). 